\title{
SISTEM PENDUKUNG KEPUTUSAN KELAYAKAN PEMBERIAN KREDIT MENGGUNAKAN METODE AHP PADA BANK DANAMON CABANG SEGIRI SAMARINDA
}

\author{
M. Irwan Ukkas ${ }^{1)}$, Amelia Yusnita ${ }^{2)}$, Eri Wandana ${ }^{3)}$ \\ ${ }^{1,2}$ Sistem Informasi, STMIK Widya Cipta Dharma \\ ${ }^{3}$ Teknik Informatika, STMIK Widya Cipta Dharma \\ $1,2,3$ Jl. Prof. M. Yamin No. 25, Samarinda, 75123 \\ E-mail : Irwan212@yahoo.com ${ }^{1)}$, lia_ameliay@yahoo.co.id ${ }^{2)}$, iwan_elbarca@yahoo.com ${ }^{3)}$
}

\begin{abstract}
ABSTRAK
Penelitian ini dilakukan bertujuan untuk menghasilkan sistem pendukung keputusan kelayakan pemberian kredit sesuai dengan nilai bobot masing-masing calon nasabah guna mendapatkan hasil layak atau tidaknya calon nasabah mendapatkan kredit.

Metode yang digunakan dalam penelitian ini adalah AHP (Analytic Hierarchy Process) yang diharapkan dapat membantu pengambil keputusan dalam mendapatkan informasi untuk menetukan apakah calon nasabah layak atau tidak layak mendapatkan kredit.

Hasil dari penelitian ini adalah dibuatnya sistem penunjang keputusan untuk kelayakan pemberian kredit. Pengguna/Credit Officer dapat menginputkan data calon nasabah, kriteria penilaian calon nasabah, kemudian sistem akan mencari nilai bobot tiap-tiap calon nasabah dengan metode AHP. Setelah nilai didapatkan, maka sistem akan menampilkan keputusan kelayakan pemberian kredit apakah calon nasabah tersebut diterima, dipertimbangkan dan ditolak dalam mendapatkan kredit
\end{abstract}

Kata Kunci: Kelayakan Kredit, Sistem pendukung Keputusan, Metode AHP

\section{PENDAHULUAN}

Bank Danamon sebagai salah satu lembaga keuangan di Indonesia yang berbentuk bank yang memberikan jasa keuangan dengan menggunakan prinsip-prinsip perbankan. Pada Bank Danamon sebelum menyalurkan dana melalui pembiayaan pada nasabah, pihak Bank terlebih dahulu melakukan penilaian nasabah (analisis pembiayaan) untuk mengetahui layak atau tidaknya nasabah tersebut menerima pembiayaan.

Sistem yang sedang berjalan dalam Pengambilan keputusan di Bank Danamon cabang Segiri Samarinda masih menggunakan proses manual dan database yang digunakan masih dalam bentuk kertas, sehingga membutuhkan waktu yang lama untuk pengolahan data nasabah. Hal ini berdampak terhadap lamanya nasabah dalam menunggu hasil keputusan dari pihak Bank.

Banyaknya perusahaan ataupun pengusaha yang mengajukan kredit ke Bank Danamon cabang Segiri Samarinda, menuntut bank harus lebih meningkatkan kualitas pelayanan terhadap nasabah. Tapi di Bank Danamon cabang Segiri, Samarinda belum menggunakan Sistem Pendukung Keputusan (SPK) berbasis komputer dikarenakan masih banyaknya karyawan yang tidak bisa menggunakan teknologi informasi secara advance, padahal sudah seharusnya di era globalisasi ini diharuskan mengetahui tentang perkembangan teknologi.

Salah satu teknik pengambilan keputusan yang digunakan dalam analisis kebijaksanaan adalah AHP (Analytic Hierarchy Process). AHP adalah prosedur yang berbasis matematis yang sangat baik dan sesuai untuk kondisi evaluasi atribut-atribut kualitatif. Atribut-atribut tersebut secara matematik dikuantitatif dalam satu set perbandingan berpasangan .

Pada hakekatnya AHP merupakan suatu model pengambil keputusan yang komprehensif dengan memperhitungkan hal- hal yang bersifat kualitatif dan kuantitatif. Dalam model pengambilan keputusan dengan AHP pada dasarnya berusaha menutupi semua kekurangan dari model-model sebelumnya. AHP juga memungkinkan ke struktur suatu sistem dan lingkungan kedalam komponen saling berinteraksi dan kemudian menyatukan mereka dengan mengukur dan mengatur dampak dari komponen kesalahan system.

Tujuan dari penelitian ini adalah untuk menghasilkan sistem pendukung keputusan kelayakan pemberian kredit sesuai dengan nilai bobot masing-masing calon nasabah 
guna mendapatkan hasil layak atau tidaknya calon nasabah mendapatkan kredit.

Hasil dari penelitian ini adalah dibuatnya sistem penunjang keputusan untuk kelayakan pemberian kredit. Pengguna/Credit Officer dapat menginputkan data calon nasabah, kriteria penilaian calon nasabah, kemudian sistem akan mencari nilai bobot tiap-tiap calon nasabah dengan metode AHP. Setelah nilai didapatkan, maka sistem akan menampilkan keputusan kelayakan pemberian kredit apakah calon nasabah tersebut diterima, dipertimbangkan dan ditolak dalam mendapatkan kredit

\section{RUANG LINGKUP PENELITIAN}

Dalam penelitian ini permasalahan mencakup:

1. Program ini berisi penentuan Kelayakan Pemberian Kredit kepada Nasabah di Bank Danamon Cabang Segiri Samarinda.

2. Terdapat 5 kriteria yang digunakan antara lain character, capacity, capital, collateral, dan condition of economic.

3. Membangun aplikasi sistem pendukung keputusan kelayakan pemberian kredit menggunakan metode AHP pada bank Danamon cabang Segiri Samarinda diharapkan dapat membantu memberikan kemudahan bagi pihak bank Danamon cabang Segiri Samarinda dalam menentukan layak atau tidaknya calon nasabah dalam mendapatkan kredit

\section{METODE PENELITIAN}

Dalam metode penelitian ada beberapa hal yang harus diperhatikan, antara lain sebagai berikut :

\subsection{Tempat dan Waktu Penelitian}

Tempat penelitian dilaksanakan di bank Danamon cabang Segiri Samarinda yang bertempat di jalan Dr. Soetomo, Samarinda, Kaltim. Waktu penelitian dimulai pada bulan september 2012 sampai dengan selesai.

\subsection{Metode AHP (Analytic Hierarchy Process)}

AHP merupakan suatu model pengambil keputusan yang komprehensif dengan memperhitungkan hal-hal yang bersifat kualitatif dan kuantitatif. Dalam model pengambilan keputusan dengan AHP pada dasarnya berusaha menutupi semua kekurangan dari model-model sebelumnya. AHP juga memungkinkan ke struktur suatu sistem dan lingkungan ke dalam komponen saling berinteraksi dan kemudian menyatukan mereka dengan mengukur dan mengatur dampak dari komponen kesalahan sistem

Proses hirarki analitik (AHP) menyediakan kerangka memungkinkan untuk membuat suatu keputusan efektif atas isu kompleks dengan menyederhanakan dan mempercepat proses pendukung keputusan. Pada dasarnya AHP adalah suatu metode dalam merinci suatu situasi yang kompleks, yang terstruktur ke dalam suatu komponen-komponennya. Artinya dengan menggunakan pendekatan AHP kita dapat memecahkan suatu masalah dalam pengambilan keputusan.

Pada dasarnya langkah-langkah dalam metode AHP meliputi :

1. Menyusun hirarki dari permasalahan yang dihadapi.
Persoalan yang akan diselesaikan, diuraikan menjadi menjadi unsur-unsurnya, yaitu kriteria dan alternatif, kemudian disusun menjadi struktur hirarki seperti gambar di bawah ini :

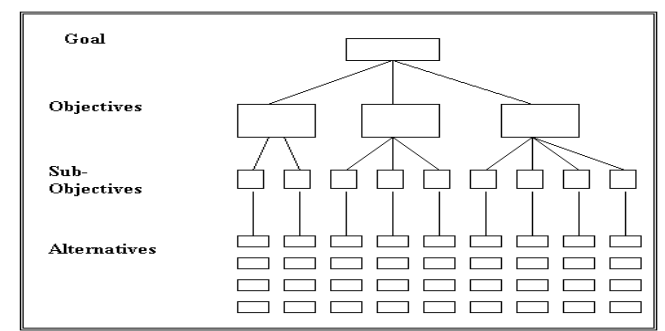

Gambar 1. Struktur Hierarki AHP

2. Penilaian Kriteria dan Alternatif

Kriteria dan alternatif dinilai melalui perbandingan berpasangan, untuk berbagai persoalan, skala 1 sampai 9 adalah skala terbaik dalam mengekspresikan pendapat. Nilai dan definisi pendapat kualitatif dari skala perbandingan dapat dilihat pada tabel 1 .

Table 1. Skala Penilaian Perbandingan berpasangan

\begin{tabular}{|c|c|}
\hline Intensitas Kepentingan & Keterangan \\
\hline 1 & $\begin{array}{c}\text { Kedua elemen sama } \\
\text { pentingnya }\end{array}$ \\
\hline 3 & $\begin{array}{c}\text { Elemen yang satu sedikit } \\
\text { lebih penting daripada } \\
\text { elemen yang lainnya }\end{array}$ \\
\hline 5 & $\begin{array}{c}\text { Elemen yang satu lebih } \\
\text { penting daripada yang } \\
\text { lainnya }\end{array}$ \\
\hline 7 & $\begin{array}{c}\text { Satu elemen jelas lebih } \\
\text { mutlak penting daripada } \\
\text { elemen lainnya }\end{array}$ \\
\hline 9 & $\begin{array}{l}\text { Satu elemen mutlak penting } \\
\text { daripada elemen lainnya }\end{array}$ \\
\hline $2,4,6,8$ & $\begin{array}{l}\text { Nilai-nilai antara dua nilai } \\
\text { pertimbangan-pertimbangan } \\
\text { yang berdekatan }\end{array}$ \\
\hline
\end{tabular}

Perbandingan dilakukan berdasarkan kebijakan pembuat keputusan dengan menilai tingkat kepentingan satu elemen terhadap elemen lainnya. Proses perbandingan berpasangan, dimulai dari level hirarki paling atas yang ditujukan untuk memilih kriteria, misalnya A, kemudian diambil elemen yang akan dibandingkan, misal A1, A2 dan A3. Maka susunan elemen-elemen yang dibandingkan tersebut akan tampak seperti pada tabel matriks di bawah ini : 
Tabel 2. Contoh Matriks Perbandingan Berpasangan

\begin{tabular}{|c|c|c|c|}
\hline & A1 & A2 & A3 \\
\hline A1 & 1 & & \\
\hline A2 & & 1 & \\
\hline A3 & & & 1 \\
\hline
\end{tabular}

Untuk menentukan nilai kepentingan relatif antar elemen digunakan skala bilangan dari 1 sampai 9 seperti pada tabel 1. penilaian ini dilakukan oleh seorang pembuat keputusan yang ahli dalam bidang persoalan yang sedang dianalisa dan mempunyai kepentingan terhadapnya.

Apabila suatu elemem dibandingkan dengan dirinya sendiri maka diberi nilai 1. jika elemen i dibandingkan dengan $\mathrm{j}$ mendapatkan nilai tertentu, maka elemen $\mathrm{j}$ dibandingkan dengan elemen i merupakan kebalikannya.

Dalam AHP ini, penilaian alternatif dapat dilakukan dengan metode yang digunakan untuk memasukkan data kuantitatif. Biasanya nilai-nilai ini berasal dari sebuah analisis sebelumnya atau dari pengalaman dan pengertian yang detail dari masalah keputusan tersebut. Jika si pengambil keputusan memiliki pengalaman atau pemahaman yang besar mengenai masalah keputusan yang dihadapi, maka dia dapat langsung memasukkan pembobotan dari setiap alternatif.

\section{Penentuan Prioritas}

Untuk setiap kriteria dan alternatif, perlu dilakukan perbandingan berpasangan. Nilai-nilai perbandingan alternatif kemudian diolah untuk menentukan peringkat alternatif dari seluruh alternatif.

Baik kriteria kualitatif, maupun kriteria kuantitatif, dapat dibandingkan sesuai dengan penilaian yang telah ditentukan untuk menghasilkan bobot dan prioritas. Bobot atau prioritas dihitung dengan manipulasi matriks atau melalui penyelesaian persamaan matematika.

\section{Konsistensi Logis}

Semua elemen dikelompokkan secara logis dan diperingatkan secara konsisten sesuai dengan suatu kriteria yang logis. Matriks bobot yang diperoleh dari hasil perbandingan secara berpasangan tersebut harus mempunyai hubungan kardinal dan ordinal

Pada keadaan sebenarnya akan terjadi beberapa penyimpangan dari hubungan tersebut, sehingga matriks tersebut tidak konsisten sempurna. Hal ini terjadi karena ketidakkonsistenan dalam preferensi seseorang. Untuk mengetahui apakah hasil penilaian bersifat konsisten, maka ada beberapa langkah untuk menghitung rasio inkonsistensi untuk menguji konsistensi penilaian atau konsistensi logis.

Penghitungan konsistensi logis dilakukan dengan mengikuti langkah-langkah sebagai berikut :

1. Mengalikan matriks dengan prioritas bersesuaian.

2. Menjumlahkan hasil perkalian per baris

3. Hasil penjumlahan tiap baris dibagi prioritas bersangkutan dan hasilnya dijumlahkan.

4. Membagi hasil dengan jumlah elemen, akan didapat $\lambda$ maks.

5. Indeks konsistensi $(\mathrm{CI})=(\lambda$ maks- $\mathrm{n}) /(\mathrm{n})$

6. Rasio Konsistensi = CI / RI, dimana RI adalah indeks random konsistensi. Jika rasio konsistensi $\leq 0.1$, hasil perhitungan data dapat dibenarkan.

Tabel 3. Nilai Indeks Random

\begin{tabular}{|c|c|}
\hline Ukuran matriks & Nilai RI \\
\hline 1,2 & 0,00 \\
\hline 3 & 0,58 \\
\hline 4 & 0,90 \\
\hline 5 & 1,12 \\
\hline 6 & 1,24 \\
\hline 7 & 1,32 \\
\hline 8 & 1,41 \\
\hline 9 & 1,45 \\
\hline 10 & 1,49 \\
\hline 11 & 1,51 \\
\hline 12 & 1,48 \\
\hline 13 & 1,56 \\
\hline 14 & 1,57 \\
\hline 15 & 1,59 \\
\hline
\end{tabular}

3.3 Pen guji

an Sistem

Pengujian sistem yang dibangun ini menggunakan metode pengujian white-box dan pengujian black-box.

Pengujian White Box bertujuan untuk menjaga integritas dari kode program (menjamin hasil keluar sesuai dengan harapan), tanpa melihat interaksi dari pengguna. Pengujian White Box berfokus pada struktur control program,

Sedangkan Pengujian Black Box berfokus pada domain informasi dari perangkat lunak, dengan melakukan test case dengan mempartisi domain input dari suatu program dengan cara memberikan cakupan pengujian yang mendalam

\section{RANCANGAN SISTEM}

Pada sistem/aplikasi ini perancangan sistem/aplikasi menggunakan Flowchart. Flowchart adalah suatu model bagan alur yang memungkinkan untuk menggambarkan sistem dokumen dari proses pelaporan yang dapat dihubungkan satu sama lain dengan alur data baik secara manual maupun terkomputerisasi.

Flowchart sistem digunakan sebagai alat untuk menjelaskan alur suatu proses yang ada pada sistem tersebut. Dengan Flowchart dapat digambarkan urutanurutan proses yang terjadi.

Flowchart Kriteria Utama dapat dilihat pada gambar berikut : 


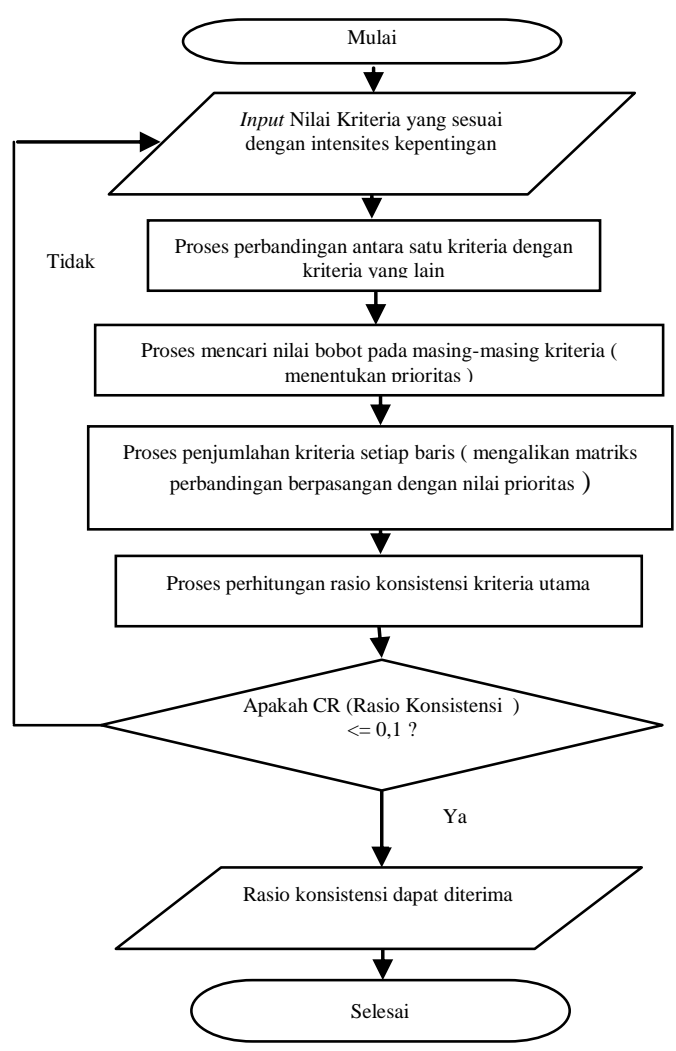

Gambar 2. Flowchart Kriteria Utama

Flowchart Subkriteria Character dapat dilihat pada gambar berikut :

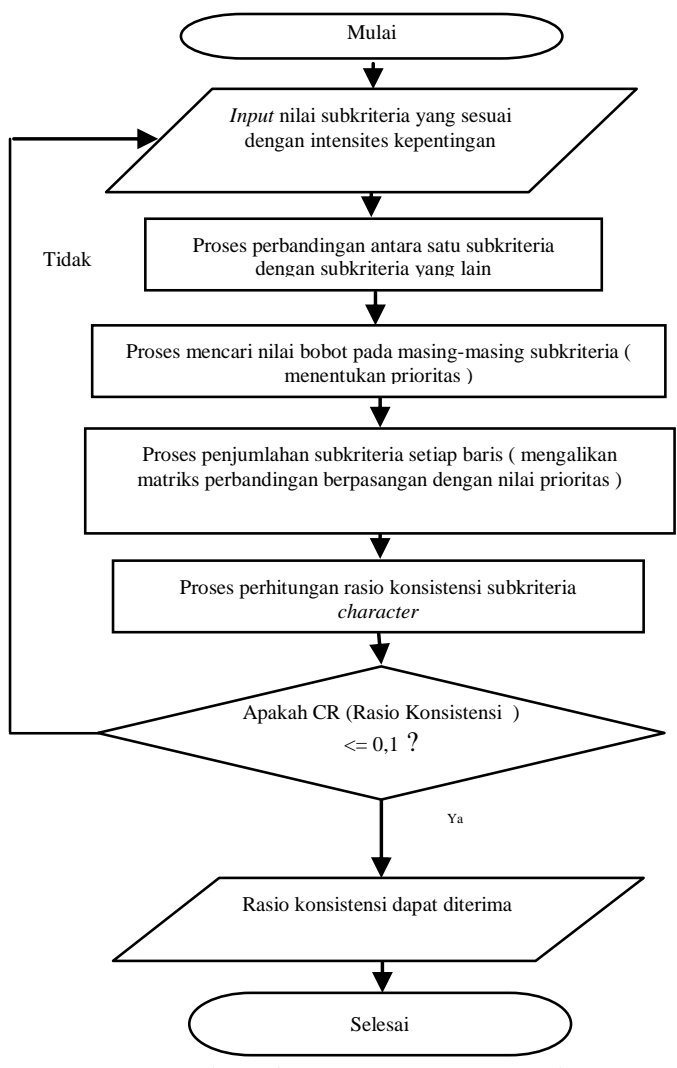

Gambar 3. Flowchart Subkriteria Character
Flowchart Subkriteria Capacity dapat dilihat pada gambar berikut :

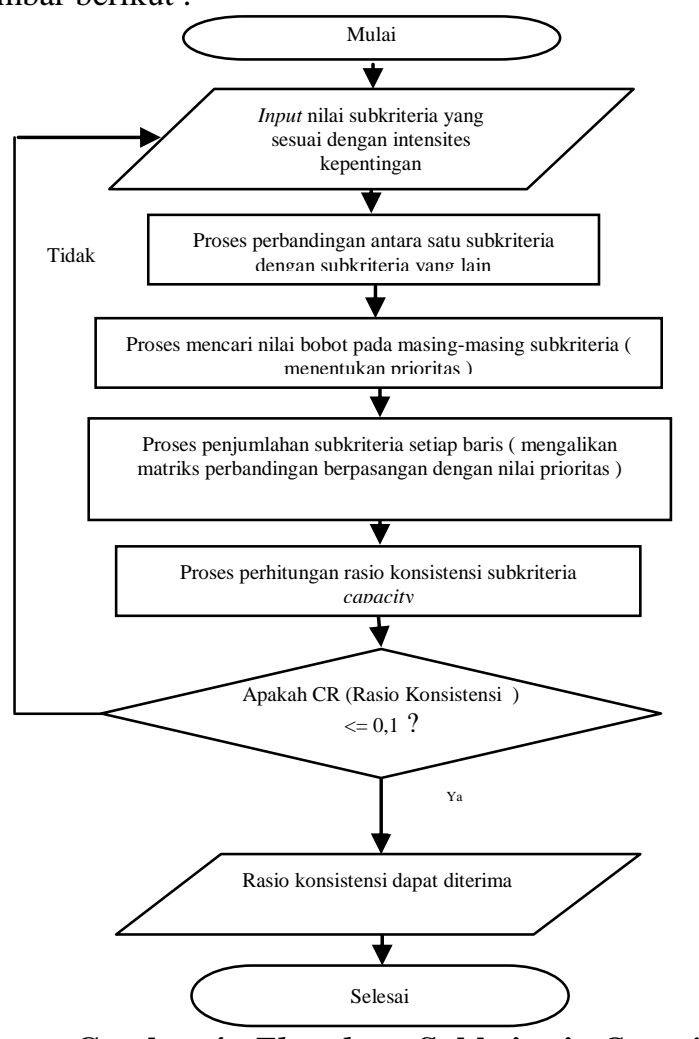

Gambar 4. Flowchart Subkriteria Capacity

Flowchart Subkriteria Capital dapat dilihat pada gambar berikut :

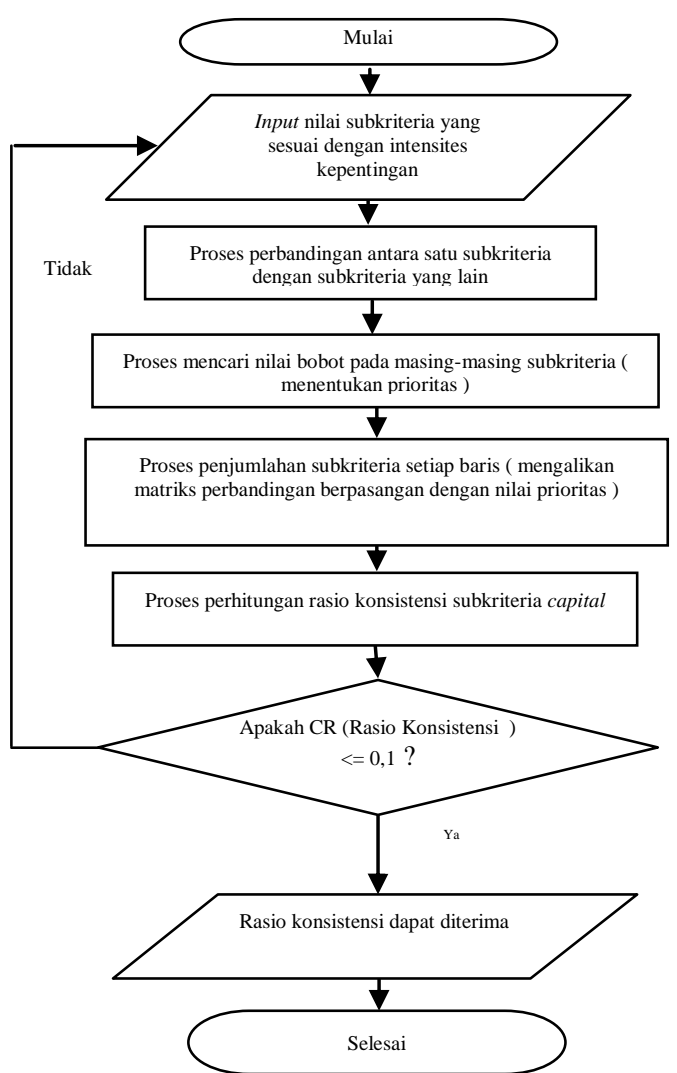

Gambar 5. Flowchart Subkriteria Capital 
Flowchart Subkriteria Collateral dapat dilihat pada gambar berikut :

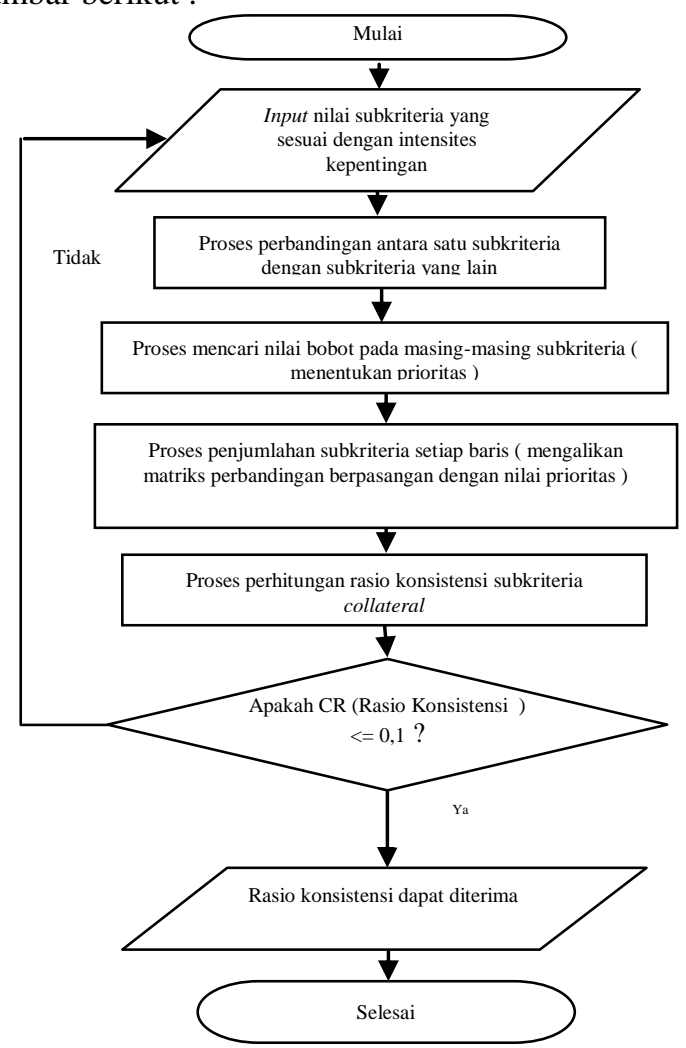

Gambar 6. Flowchart Subkriteria Collateral

Flowchart Subkriteria Condition of Economic dapat dilihat pada gambar berikut :

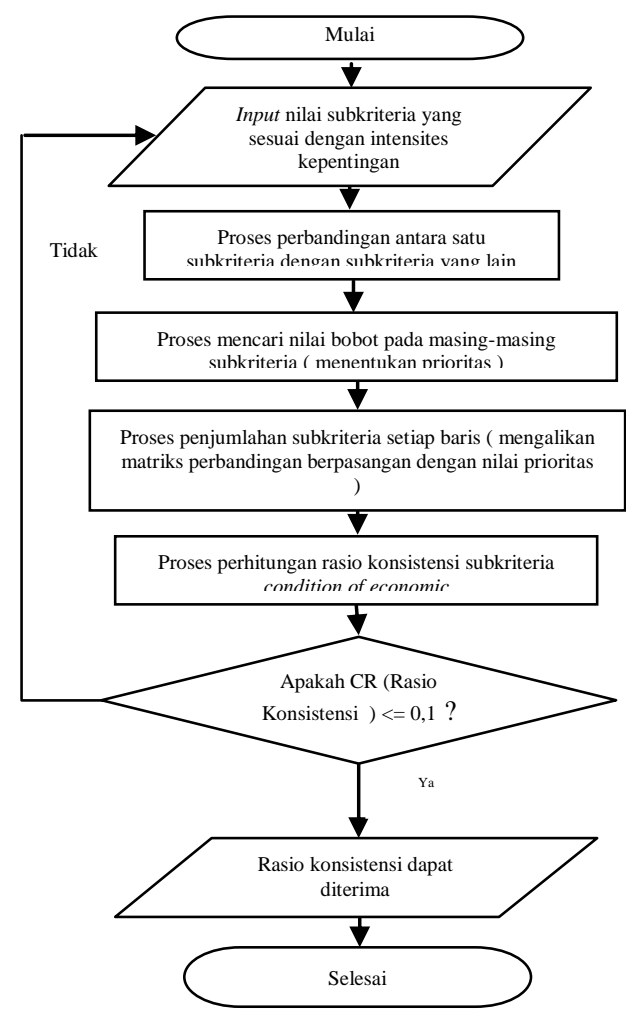

Gambar 7. Flowchart Subkriteria Condition of economic

\section{IMPLEMENTASI}

Gambar 8. Merupakan tampilan dari Menu Utama

\section{Gambar 8. Tampilan Menu Utama}

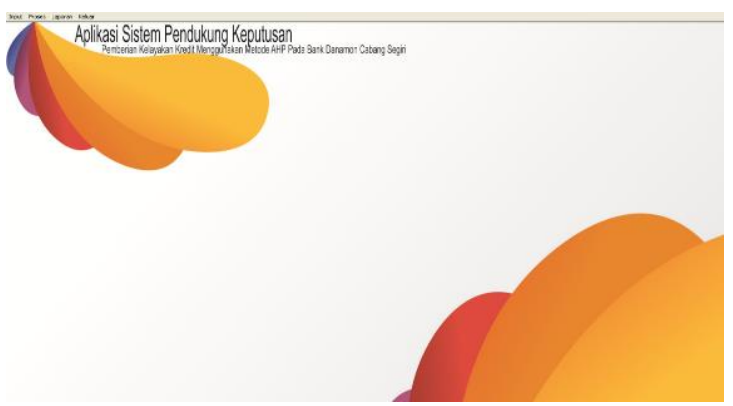

Gambar 9. Merupakan tampilan Input Data Nasabah

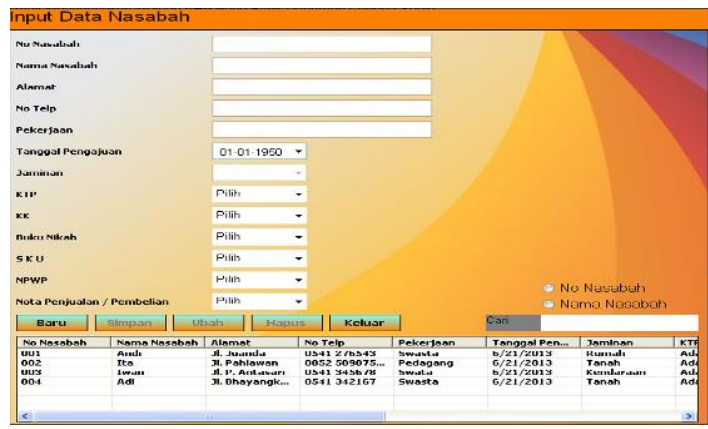

Gambar 9. Tampilan Input Data Nasabah

Gambar 10. Merupakan tampilan Input Matrik Kriteria Utama

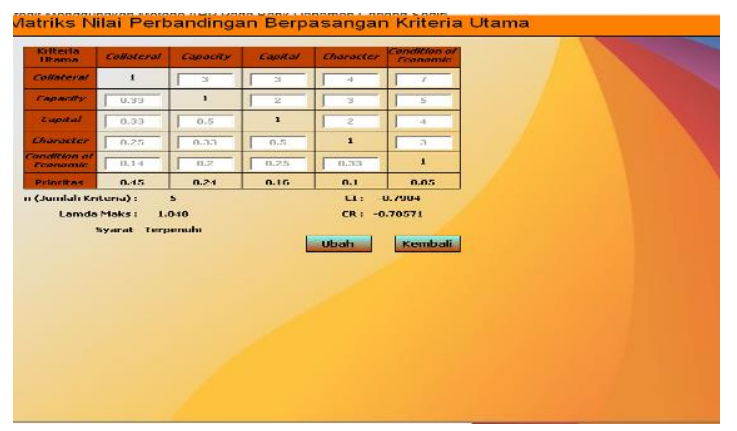

\section{Gambar 10. Tampilan Input Matrik Kriteria Utama}

Gambar 11. Merupakan Tampilan Input Matrik Collateral

\section{Gambar 11. Tampilan Input Matrik Collateral}

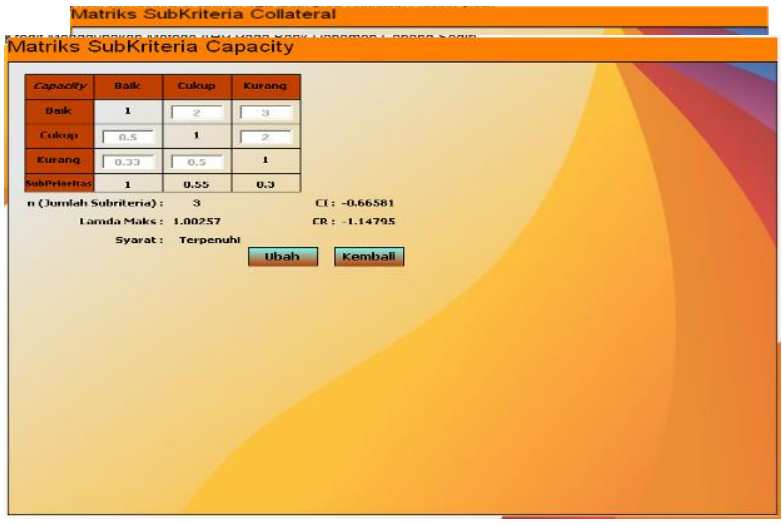

Gambar 12. Merupakan Tampilan Input Matrik Capacity 
Gambar 12. Tampilan Input Matrik Capacity

Gambar 13. Merupakan Tampilan Input Matrik Capital

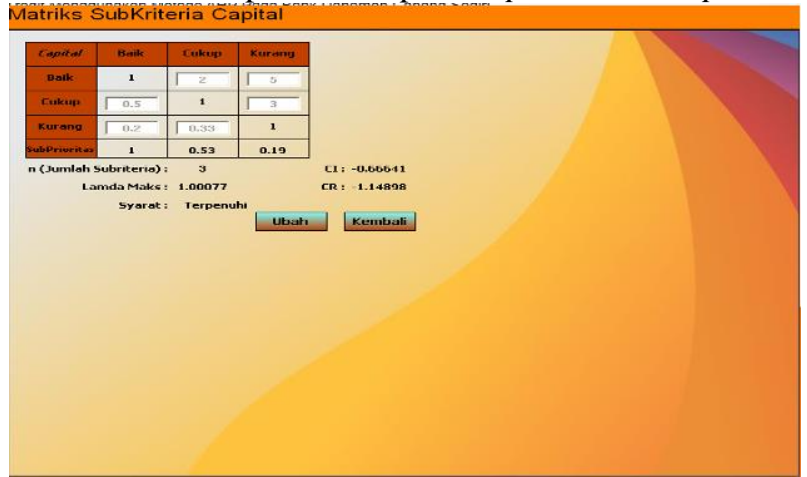

Gambar 13. Tampilan Input Matrik Capital

Gambar 14. Merupakan Tampilan Input Matrik Character

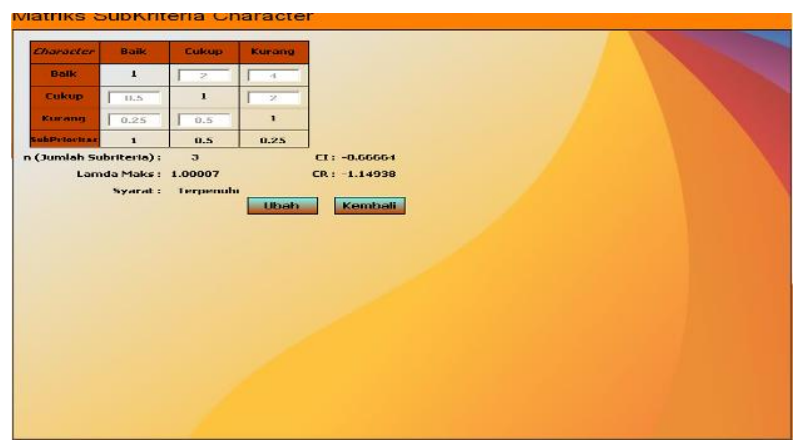

Gambar 14. Tampilan Input Matrik Character

Gambar 15. Merupakan Tampilan Input Matrik Condition of Economic

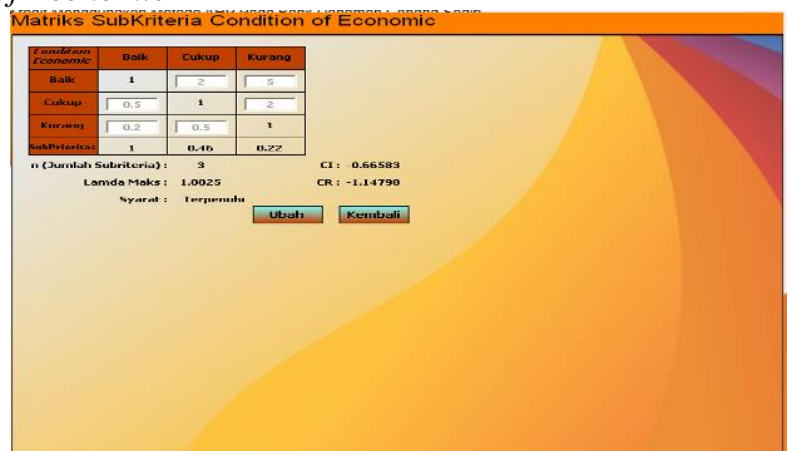

Gambar 15. Tampilan Input Matrik Condition of Economic

Gambar 16. Merupakan Tampilan Hasil Perhitungan Matrik

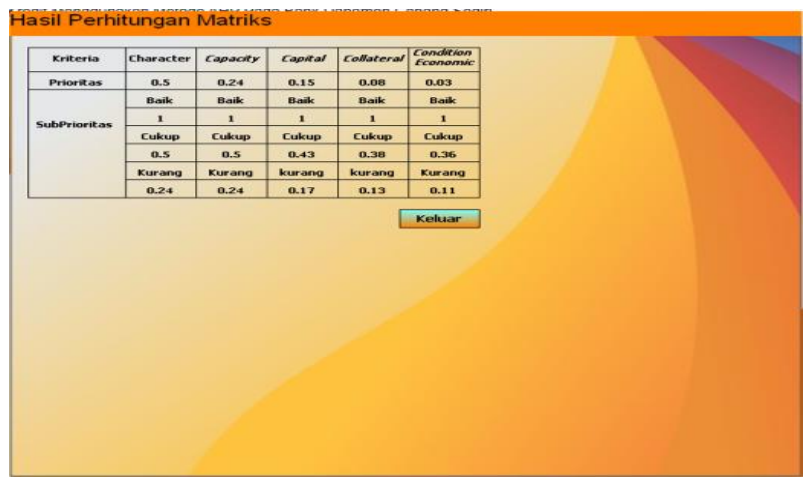

\section{Gambar 16. Tampilan Hasil Perhitungan Matrik}

Gambar 17. Merupakan Tampilan Hitung Nilai Bobot Nasabah

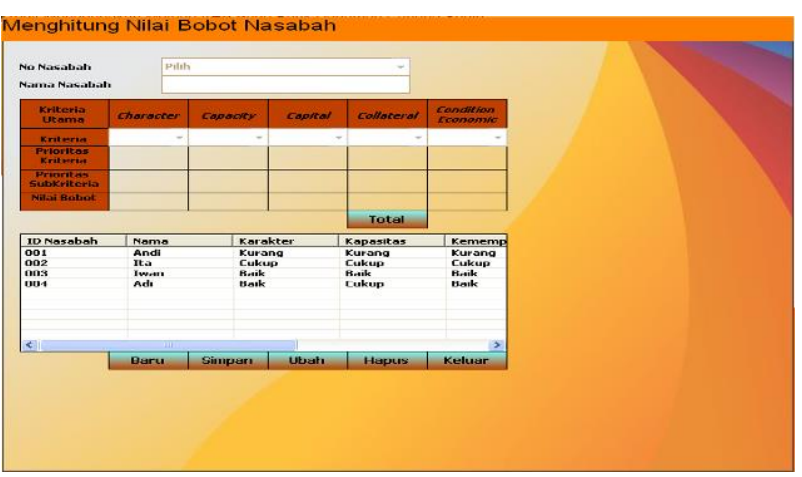

Gambar 17. Tampilan Hitung Nilai Bobot Nasabah

Gambar 18. Merupakan Tampilan Cetak Laporan

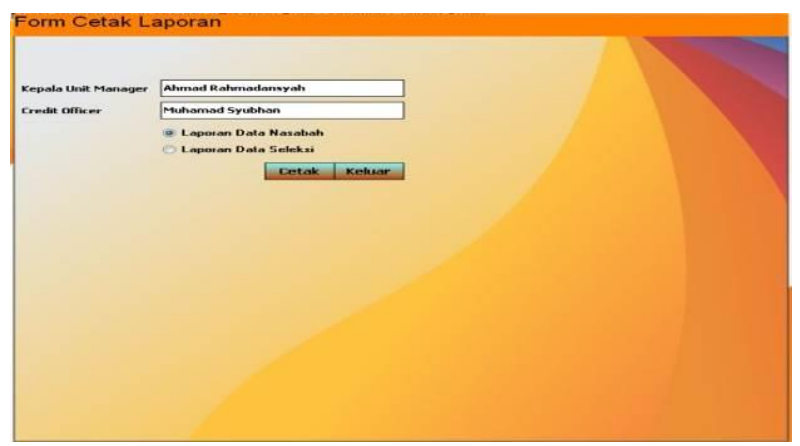

Gambar 18. Tampilan Cetak Laporan

Gambar 19. Merupakan Tampilan Laporan Data Nasabah

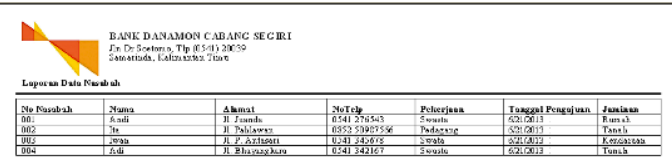

Gambar 19. Tampilan Laporan Data Nasabah

Gambar 20. Merupakan Tampilan Laporan Data Seleksi Nasabah

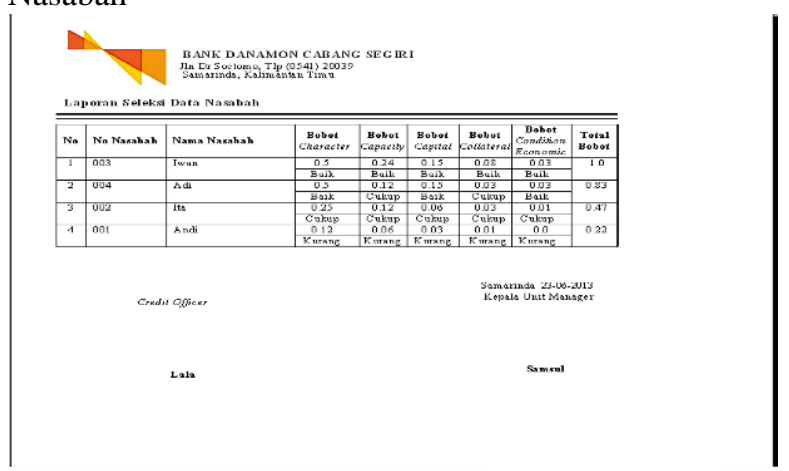

Gambar 20. Tampilan Laporan Data Seleksi Nasabah 


\section{KESIMPULAN}

Dari hasil yang telah dilaksanakan, dapat disimpulkan bahwa Aplikasi Sistem Pendukung Keputusan Kelayakan Pemberian Kredit Menggunakan Metode AHP pada Bank Danamon Cabang Segiri Samarinda sebagai berikut:

1. Hasil akhir dari sistem aplikasi ini, diperoleh nilai total bobot dari calon nasabah yang bernilai 1 atau mendekati nilai 1 . Karena nilai total bobot inilah yang dijadikan dasar sebagai nilai prioritas calon nasabah yang dapat di rekomendasikan untuk mendapatkan kredit atau tidak mendapatkan kredit.

2. Kelebihan dari sistem aplikasi ini, dapat membantu kinerja pihak bank dalam pengambilan keputusan dalam menentukan layak atau tidaknya calon nasabah tersebut dalam penerimaan kredit.

3. Kekurangan dari sistem aplikasi ini masih bersifat statis, yang dapat diubah baru nilai bobotnya saja.

\section{SARAN}

1. Aplikasi Sistem Pendukung Keputusan Kelayakan Pemberian Kredit Menggunakan Metode AHP Pada Bank Danamon Cabang Segiri Samarinda ini khusus digunakan untuk menentukan layak atau tidak nasabah tersebut diberikan kredit pinjaman, maka peneliti menyarankan agar kedepannya sistem ini bisa dikembangkan..

2. Aplikasi Sistem Pendukung Keputusan Kelayakan Pemberian Kredit Menggunakan Metode AHP Pada Bank Danamon Cabang Segiri Samarinda ini dapat dikembangkan lebih lanjut bagi pihak-pihak yang termotivasi untuk melakukan pengembangan terhadap sistem ini agar sistem dapat menjadi lebih optimal.

3. Aplikasi Sistem Pendukung Keputusan Kelayakan Pemberian Kredit Menggunakan Metode AHP Pada Bank Danamon Cabang Segiri Samarinda ini masih bersifat statis, yang dapat diubah baru nilai bobotnya saja. Diharapkan kedepannya, sistem ini dapat dikembangkan menjadi lebih dinamis sehingga jumlah kriteria atau jumlah sub kriterianya bisa diubah. Baik itu menambah atau mengurangi jumlah kriteria dan sub kriteria yang ada.

\section{DAFTAR PUSTAKA}

Departemen Pendidikan Nasional, 2003. Kamus Besar Bahasa Indonesia. Jakarta : Balai Pustaka.

Daihani, D.U, 2001, Komputerisasi Pengambilan Keputusan,PT.Gramedia,Jakarta. expresiaku.wordpress.com/2009/02/23/306/

Fakir Husein M, dan Wibowo A, 2002 Sistem Informasi Manajemen, Jogyakarta : Edisi Pertama Februari.

Hasan Iqbal. M, 2004, Teori Pengambilan Keputusan (Pokok-pokok Materi), Ghalia Indonesia, Jakarta

Kadir, Abdul, 2002, Pengenalan Sistem Informasi, Andi Offset, Yogyakarta.
Kristanto, Andi, 2003. Perancangan Sistem Informasi dan Aplikasinya.Yogyakarta : Gava Media.

Kusrini Mukhsin, A. 2007. Sistem Pendukung Keputusan Penerbit Gava Media Jakarta

Madcoms, 2007, Microsoft Access 2007 Untuk Pemula, Penerbit Andi, Yogyakarta.

Pressman, Roger. 2002. Rekayasa Perangkat Lunak Pendekatan Praktisi. Yogyakarta : Penerbit Andi.

Saaty, T. L, 2008, Decision Making For Leaders Forth Edition, University of Pittsburgh, RWS Publication

Sprague, 2004, Information System Management In Practice, Englewood Cliffts, New Jersey : PrenticeHall Inc

Sudirman dan Widjajani, 2002 Aplikasi Pendukung Keputusan, Jakarta, Penerbit Fakultas Ekonomi Universitas Indonesia

Suryadi.,K. dan Ramdhani,M.A.,1998, Sistem PendukungKeputusan, PT. Remaja Rosdakarya, Bandung.

Turban, 2005, Dessicion Support System and Intelligent System, Penerbit Andi, Yogyakarta. 